Crop Breeding and Applied Biotechnology 16: 7-13, 2016

Brazilian Society of Plant Breeding. Printed in Brazil

\title{
ARTICLE
}

http://dx.doi.org/10.1590/1984-70332016v16n1a2

\section{Pathogenic variability of Moniliophthora perniciosa in three agroecological zones of the cacao region of Bahia, Brazil}

Karina Peres Gramacho ${ }^{1 *}$, Edna Dora Martins Newman Luz ${ }^{1}$, Fernanda Santos da Silva ${ }^{2}$, Uilson Vanderlei Lopes ${ }^{1}$, Jose Luis Pires ${ }^{1}$ and Lindolfo Pereira ${ }^{1}$

Received 12 November 2014

Accepted 24 September 2015

\begin{abstract}
Resistant cacao genotypes are the best measure to control the Witches' broom disease of cacao. To ensure efficiency, the pathogen variability in the cacao region of Bahia must be investigated. The pathogenic variability of Moniliophthora perniciosa inocula from nine municipalities was analyzed: Ilhéus, Floresta Azul and Jussari (agroecological zone Almada); Ipiaú, Itagibá and Jitaúna (agroecological zone Ipiaú), Camacan, Santa Luzia and Pau Brasil (agroecological zone Camacan), by inoculating progenies of Sca 6, ICS 1 and SIC 23 seedlings with $2 \times 10^{5}$ basidiospore. $\mathrm{mL}^{-1}$ of inocula and inoculum mixtures per agroecological zone, in a factorial $3 \times 13$ design, with 4 replications of 28 plants, in two seasons. Symptoms were assessed 60 days after inoculation. Pathogenic variability of inoculum in relation to the progeny performance was found; Ipiau was the most aggressive and progeny ICS 1 the most susceptible. The mixtures of the agroecological zones Almada and Ipiaú were contrasting.
\end{abstract}

Key words: Genetic improvement, resistance, Theobroma cacao L., witches' broom.

\section{INTRODUCTION}

The witches' broom disease of cacao (WBD) (Theobroma cacao L.), caused by the basidiomycete Moniliophthora (= Crinipellis) perniciosa (Stahel) Aime and PhillipsMora (Aime and Phillips-Mora 2005), is one of the most destructive cacao diseases. In Brazil, it led to high losses in cacao production in the main cacao-producing region of Brazil, the State of Bahia, causing the country to become a cacao importer (Luz et al. 2006). The disease, known to induce overgrowth and hypertrophy in the branches, fruits and flower cushions, may lead to plant death after successive attacks of the pathogen, favored by abiotic factors. The main component in WBD management is genetic resistance. However, despite repeated releases of plant material with resistance and high yield, the descendants of Scavina clones still predominate as the main sources of resistance in Brazil, as well as in other producing countries (Lopes et al. 2011). Unfortunately, in some of these sources, even in the Scavinas descendants, the disease incidence has increased significantly since 2003 (Paim et al. 2006), due to pathogen adaptation (Gramacho et al. 2008). Thus, the Cacao breeding program of CEPLAC-CEPEC has introduced new genotypes carrying
WBD-resistant genes from different sources to increase resistance durability in the cultivated areas, hampering pathogen adaptation and increasing the frequency of the most aggressive types (Gramacho et al. 2008).

Knowledge about the pathogenic variability of $M$. perniciosa in southeastern Bahia is necessary to support the selection of cacao resistant genotypes and the implementation of the other measures of integrated management of cacao diseases, with a view to ensure the sustainability of the crop in the region. As a contribution to this knowledge, the pathogenic variability in inocula from different municipalities and three agroecological zones was analyzed as well as the possibility of using mixtures of inocula for screening for resistance.

\section{MATERIAL AND METHODS}

The experiments were carried out in the facilities of the Plant Pathology unit of the Cacao Research Center (CEPEC), at the headquarters of the Executive Committee of the Plan of Cacao Farming (CEPLAC), Ilhéus, BA, Brazil.

\section{Inoculum preparation}

\footnotetext{
${ }^{1}$ CEPLAC, Centro de Pesquisas do Cacau (CEPEC), Rod. Ilhéus-Itabuna, km 22, 45.600-000, Itabuna, BA, Brazil. *E-mail: karina@ceplac.gov.br

${ }^{2}$ Universidade Estadual de Santa Cruz (UESC), 45.662-000, Ilhéus, BA, Brazil
} 
The inocula of $M$. perniciosa were obtained from dry brooms collected in a same period from cacao trees in nine municipalities, in three agroecological zones of the cacao region of Bahia: Ilhéus, Floresta Azul and Jussari (agroecological zone - Almada); Ipiaú, Itagibá and Jitaúna (agroecological zone - Ipiaú), Camacan, Santa Luzia and Pau Brasil (agroecological zone - Camacan). The sampled brooms were labeled according to their location. At the laboratory, they were sterilized with quick rinses in $0.1 \%$ sodium hypochlorite and hung in a chamber in which they were maintained wet for $8 \mathrm{~h}$ and dry for $16 \mathrm{~h}$ every day to induce basidiome formation. Mature basidiomes were removed, disinfected and dried on paper towels. The pilei were removed and fixed with pasty Vaseline (Silinol $\mathrm{SG}$ ) on glass covers, with the hymenium face-down, on a beaker containing a $16 \%$ glycerol solution, and constantly shaken for $20 \mathrm{~h}$ to release the basidiospores (Dickstein et al. 1987). The concentrations of the obtained basidiospore suspensions were measured on a spore or cell counter (Coulter counter), and thereafter placed in $2 \mathrm{ml}$ cryogenic vials and stored in liquid nitrogen for later use. The germination of basidiospores was observed $24 \mathrm{~h}$ before inoculation to determine the inoculum viability, choosing those with more than $80 \%$ germinated spores. On the day of inoculation, the basidiospore suspensions from the nine municipalities were removed from the liquid nitrogen, and diluted to $2 \times 10^{5}$ basidiospores $\mathrm{mL}^{-1}$ (Dickstein et al. 1987). In addition to the nine inocula per municipality, three inoculum mixtures per agroecological zone were used: mixture A - from Almada; mixture B - from Ipiaú and mixture C - from Camacan. The mixtures consisted of a well-mixed blend of $5 \mathrm{~mL}$ of inocula of each municipality of each agroecological zone at the time of inoculation.

\section{Plant material}

Seeds from three open-pollinated cacao clones: ICS 1, SIC 23 (susceptible) and Sca 6 (resistant) were used. The seeds were pre-germinated for 48 hours in sterile moistened sawdust and planted in plastic tubes containing approximately $300 \mathrm{~g}$ of seasoned compost. The seedlings were maintained in a greenhouse and irrigated three times a day (at 8, 12 and $16 \mathrm{~h}$ ) for 15 minutes. Three to four weeks after planting, 112 seedlings of each progeny were selected for inoculation with each of the 12 inocula and one uninoculated control.

\section{Inoculation}

Inoculation was performed as described by SurujdeoMaharaj et al. (2004), with minor modifications, briefly: one day before inoculation, the size of the existing leaves was reduced by $2 / 3$; each seedling was inoculated with a $20 \mu \mathrm{L}$ drop of the specific inoculum suspension at a concentration of $2 \times 10^{5}$ basidiospores $\mathrm{mL}^{-1}$, placed on the apical bud; controls received a drop of $0.2 \%$ water-agar; maintained in a moist chamber for $24 \mathrm{~h}$ after inoculation, at a temperature of $23 \pm 2{ }^{\circ} \mathrm{C}$ and $100 \% \mathrm{RH}$, and transferred to the greenhouse.

\section{Evaluation}

At 30 and 60 days after inoculation, each plant was evaluated for the broom type, amount of axillary brooms, and broom diameter and height when the main symptom was terminal broom. Two variables were used to analyze aggressiveness:

SYMP = percentage of plants with disease symptoms, e.g., terminal, axillary, cotyledon or dry brooms, swelling of the stem, hypocotyl, petioles and pulvini, canker, stem bunching or hypertrophy; $\mathbf{D I}=$ Disease index calculated by the following formula:

$$
\mathrm{DI}=\mathrm{TB}+\mathrm{AB}(0.5 \mathrm{CVT})+\mathrm{NAB}
$$

Where:

$\mathrm{TB}$ is the number of terminal brooms; $\mathrm{AB}$ is the number of axillary brooms; LTB is the length of terminal broom, and NAB is the number of axillary brooms larger than 1 .

The variable SYMP, a discrete binary variable in which 1 and 0 represent, respectively, the presence and absence of symptoms, measures the disease incidence, while DI measures disease severity.

\section{Data design and analysis}

The experiments were arranged in a completely randomized design with 4 replications of 28 seedlings each (experimental unit), i.e., 112 seedlings per treatment (12 inocula +1 control) in a factorial design ( 3 progenies x 13 inocula) - resulting in a total of 4,368 seedlings per experiment (1,456 seedlings per genotype). Within six months, the experiment was repeated under equal conditions. A linear model in which all factors were considered fixed, in a hierarchical or nested scheme, was used (Neter et al. 1990). The inocula were nested within the municipality of origin. To estimate the variance components and verify whether the inoculum interaction (agroecological zone $\mathrm{x}$ progeny) was significant, the following model was adjusted:

$$
\operatorname{Yijk}(\text { SYMP, DI })=\mu+\alpha \mathrm{i}+\beta \mathrm{j}(\mathrm{i})(\alpha)+\text { eijk }
$$

Where:

$\mu=$ the general mean fitted; $\alpha \mathrm{i}=$ agroecological zone effect; $\beta \mathrm{j}(\mathrm{i})(\alpha)=$ effect of inocula nested within agroecological 
zone, and eijk $=$ error

It was used the procedure PROC GLM of software SAS (1988). The same was done for inoculum (municipality $\mathrm{x}$ progeny). The contrasts between the means of the mixtures of inocula and the arithmetic mean of the inocula per agroecological zone and per progeny were evaluated by the $\mathrm{F}$ test. The means were compared by the Tukey test (5\%).

To study the possibility of using inoculum mixtures as sources for screening for resistance to M. perniciosa, a fourth treatment was included in the experiments, which consisted of inoculum mixtures from each municipality of that agroecological zone, as follows: mixture A (Almada), mixture B (Ipiaú) and mixture C (Camacan). Differences per progeny within and between each agroecological zone were tested by ANOVA and means compared by the Tukey test.

\section{RESULTS AND DISCUSSION}

Since there was no significant effect $(p>0.05)$ for the two seasons in which the experiment was repeated, the data were analyzed together. The analysis of variance detected significant $F$ values $(p<0.05)$ for the two variables SYMP and DI for: i) progenies; ii) inocula from different agroecological zones; and iii) between inocula within each agroecological zone. A significant effect $(p<0.05)$ of the interaction between progeny and agroecological zone was also observed.

The SYMP and DI values of inoculum from the agroecological zone Ipiaú were higher (37\% and 1.05, respectively) differing statistically from the other agroecological zones (Table 1). There was no significant difference $(p>0.05)$ between the means of inocula from the agroecological zones Almada and Camacan for both variables. For SYMP, the values were $17 \%$ for Camacan

Table 1. Disease incidence (SYMP) and severity (DI) of witches' broom disease on cacao seedlings inoculated with $M$. perniciosa inoculum from municipalities of three agroecological zones

\begin{tabular}{lccc}
\hline Agroecological zone & Municipality & Symp (\%) & DI \\
\hline Almada & Ilhéus & $30 \mathrm{BC}$ & $0.67 \mathrm{BC}$ \\
& Floresta Azul & $18 \mathrm{BC}$ & $0.41 \mathrm{BC}$ \\
& Jussari & $22 \mathrm{BCD}$ & $0.37 \mathrm{C}$ \\
Ipiaú & Ipiaú & $51 \mathrm{~A}$ & $1.54 \mathrm{~A}$ \\
& Jitaúna & $24 \mathrm{BCD}$ & $0.66 \mathrm{BC}$ \\
& Itagibá & $35 \mathrm{AB}$ & $0.96 \mathrm{~B}$ \\
Camacan & Camacan & $17 \mathrm{CD}$ & $0.42 \mathrm{BC}$ \\
& Santa Luzia & $25 \mathrm{BCD}$ & $0.69 \mathrm{BC}$ \\
& Pau Brasil & $11 \mathrm{D}$ & $0.28 \mathrm{C}$ \\
\hline
\end{tabular}

Means followed by the same letter are not significantly different by the Tukey test at $\mathrm{p}<0.05$.

$\mathrm{SYMP}=$ presence or absence of witches' broom symptoms; DI = index of witches' broom disease in Theobroma cacao L. progenies and $23 \%$ for Almada, while for DI values obtained were 0.46 and 0.48 , respectively.

There was variation in the performance of inocula from different municipalities, without differentiating progenies. The SYMP means ranged from $11 \%$ (Pau Brasil) to $51 \%$ (Ipiaú) DI and from 0.28 (Pau Brasil) to 1.54 (Ipiaú) (Table 1). Inoculum from Ipiaú, followed by that from Itagibá, both of the agroecological zone Ipiaú, were most aggressive to the tested genotypes. A second group was formed by the inocula from Ilhéus, Floresta Azul, Jitaúna, and Santa Luzia, for SYMP as well as for DI. There were only variations in the performance of inocula from Camacan and Jussari since for SYMP, the lowest means were of inocula from Camacan (17\%) and Pau Brasil (11\%) and for DI, from Pau Brasil (0.28) and Jussari (0.37). The performance of the three progenies also varied for the two variables. For SYMP, progeny ICS $1(39 \%)$ had significantly $(\mathrm{p}<0.05)$ greater disease incidence than the others with $16 \%$ (Sca 6) and 22\% (SIC 23), which did not differ from each other (Figure 1A). For DI, ICS 1 had a significantly $(\mathrm{p}<0.05)$ higher value than Sca 6, while SIC 23 did not differ from
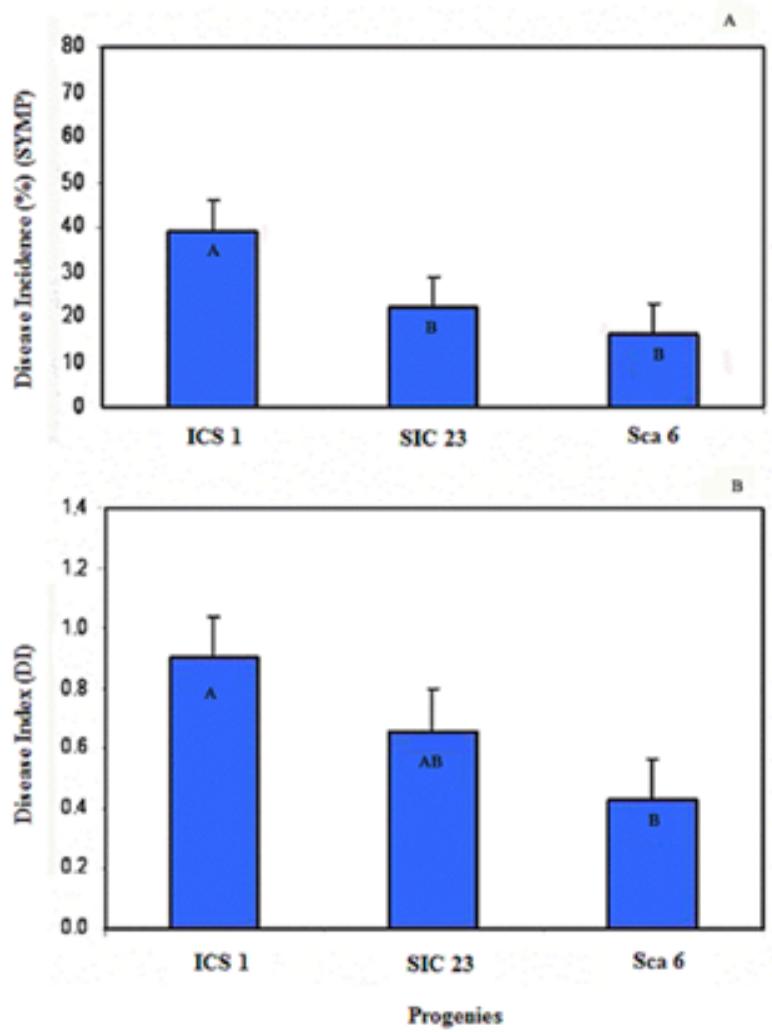

Figure 1. Performance of progenies of cacao clones ICS 1, SIC 23 and Sca 6 based on disease incidence (A) and disease index (B) of witches' broom disease. 
the others and had an intermediate response (Figure 1B). Table 2 shows the results for the aggressiveness of inocula from each agroecological zone. The inoculum from Ipiaú was most aggressive for all progenies. In addition, the inocula of the agroecological zones Almada and Ipiaú were significantly $(p<0.05)$ more aggressive to progeny ICS 1 than those from Camacan, while for progeny Sca 6, inoculum from Ipiaú was more aggressive than that of the agroecological zone Almada.

For progeny ICS 1, in the two variables and the three agro-systems, there were no statistical differences between the means of the four treatments, as also observed for progenies Sca 6 and SIC 23 in the agroecological zone Camacan (Table 3). However, in the agroecological zones Almada and Ipiaú, there was a difference between the progenies Sca 6 and SIC 23. In Almada, for the two progenies and both variables, the mean of inocula and the inocula from Ilhéus and Jussari were more aggressive to progeny Sca 6 and for SIC 23 for variable SYMP, because for DI, only inoculum from Ilhéus did not differ statistically from the overall mean. Seedlings of the two progenies (Sca 6 and SIC 23) had lower SYMP and DI means when inoculated with basidiospores from
Floresta Azul. For the agroecological zone Ipiaú, the overall means for SYMP and DI in the progenies Sca 6 and SIC 23 were not significantly different from inoculum from Ipiaú, but statistically different from the inoculum from Jitaúna, which was the least aggressive.

The arithmetic mean was calculated for each variable, genotype and agroecological zone, from the values of the three inocula within each agroecological zone. These means were compared to the mean values obtained for the inoculum mixture of the same agroecological zone by contrast analysis (Table 4). It was observed that, for the agroecological zone Camacan, the contrasts for all progenies among the general means of inocula per municipality, and the mean of the mixtures were not significant ( $p>0.05)$. For progeny ICS 1 , only contrast to the variable DI in the agroecological zone Almada was significant $(p<0.05)$. For Sca 6 and SIC 23, the contrasts were significant $(p<0.05)$ for both variables in Almada and Ipiaú. However, while in Almada, the means of the mixtures were higher than those of inocula applied individually, the opposite occurred in the agroecological zone Ipiaú.

Table 2. Mean percentage of infection (SYMP) and mean disease index (DI) in three cacao progenies for $M$. perniciosa inocula obtained from three agroecological zone in the cacao region of Bahia

\begin{tabular}{|c|c|c|c|c|c|c|}
\hline \multirow{3}{*}{ Agroecological zones } & \multicolumn{6}{|c|}{ Genotype/Variable } \\
\hline & \multicolumn{2}{|c|}{ ICS 1} & \multicolumn{2}{|c|}{ Sca 6} & \multicolumn{2}{|c|}{ SIC 23} \\
\hline & SYMP (\%) & DI & SYMP (\%) & DI & SYMP (\%) & DI \\
\hline Almada & $48 \mathrm{~A}$ & $0.99 \mathrm{~A}$ & $11 \mathrm{~B}$ & $0.20 \mathrm{~B}$ & $10 \mathrm{~B}$ & $0.26 \mathrm{~B}$ \\
\hline Camacan & $22 \mathrm{~B}$ & $0.47 \mathrm{~B}$ & $15 \mathrm{AB}$ & $0.44 \mathrm{AB}$ & $16 \mathrm{~B}$ & $0.48 \mathrm{~B}$ \\
\hline
\end{tabular}

Means followed by the same letter are not significantly different at $\mathrm{p}<0.05$ by the Tukey test; SYMP $=$ presence or absence of witches' broom symptoms; DI $=$ index of witches' broom disease in Theobroma cacao L. progenies.

Table 3. Percentage of infection and mean disease index obtained for the three progeny (ICS 1, Sca 6 and SIC 23) when inoculated with basidiospore suspension obtained from each municipality in each agroecological zone

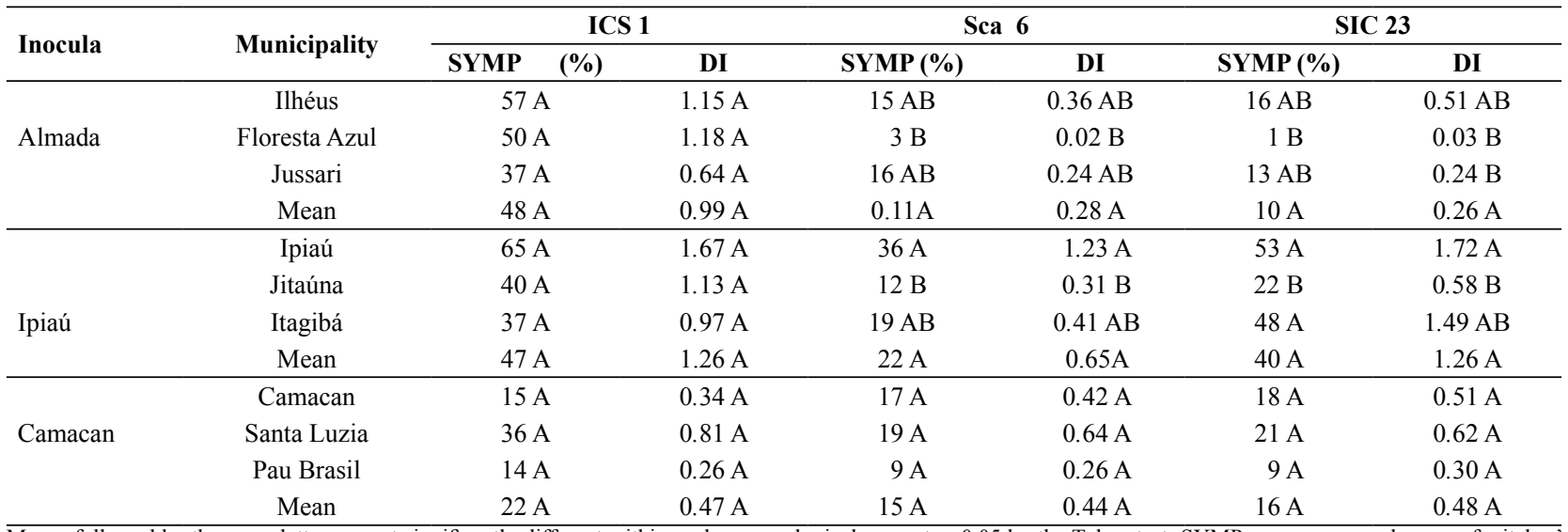

Means followed by the same letter are not significantly different within each agroecological zone at $\mathrm{p}<0.05$ by the Tukey test; SYMP $=$ presence or absence of witches' broom symptoms; DI = index of witches' broom disease in Theobroma cacao L. progenies. 
Based on the different degrees of disease severity (DI) and incidence (SYMP) of WBD in the studied progenies, the conclusion drawn in this study was that the M. perniciosa inocula have pathogenic variability. The inoculum from Ipiaú was more efficient in causing infection in inoculated cacao seedlings than that from Almada and Camacan, with a higher mean DI, more than the double of the damage caused by inocula from the other two agroecological zones.

Witches' broom was detected in Bahia in 1989 in the municipality of Uruçuca (agroecological zone Almada), and later in Camacan (agroecological zone Camacan), and reached the other agroecological zones of the cacao region in the same year (Pereira 1996). At that time, the diseased areas in cacao plantations were classified in three levels, according to the percentage of plants/area of a property with disease symptoms. The infection level on farms differed significantly, since, according to the system proposed by Lisboa (1998), in 1991 on most farms located in the agroecological zones Camacan and Almada the disease was at level 3 (infection of over $30 \%$ of plants per acreage) and many properties were abandoned, while in Ipiaú, the infection level of the cacao plantations was classified as level 1 (infection of up to $10 \%$ of plants per field). The higher aggressiveness of inoculum from the agroecological zone Ipiaú than from Almada and Camacan was possibly due to the fact that the epidemic phase of the disease was then still exponential. Even when a small sample per agroecological zone was used, differences in the aggressiveness of $M$. perniciosa were observed among them, demonstrating the adaptation potential of the pathogen to different geographic areas in the cacao region of Bahia.

The most aggressive inoculum among those from the agroecological zone Ipiaú was found in the municipality of Ipiaú, followed by that from Itagibá, while that from Jitaúna was in an intermediate group (Table 1). This indicates variation among inocula of this agroecological zone, as similarly observed for the agroecological zone Almada compared with inoculum from Ilhéus and Camacan, with regard to that from Pau Brasil, the least aggressive of the tested inocula.

The existence of at least three somatic compatibility groups was observed by Oliveira et al. (2006), which were randomly termed groups $\mathrm{A}, \mathrm{B}$ and $\mathrm{C}$, in a study of $135 \mathrm{M}$. perniciosa isolates obtained by sampling and isolation of infected material collected in different agroecological zones of cacao. Groups A and B were better represented than $\mathrm{C}$. Interestingly, isolates of group A predominated in the agroecological zones Almada (64.5\%) and Camacan $(90 \%)$, while in agroecological zone Ipiaú, $70.6 \%$ those of Group B. Although the relationship between pathogenic and sexual compatibility was not discussed in this study, the detected differences in pathogenicity were possibly related to the different $M$. perniciosa populations present in the cacao region of Bahia.

Molecular evidence for the genetic variability among

Table 4. Values of probability (F test) to reject the null hypothesis contrast between the means of progenies per variable and agroecological zone, and the mean of the inoculum mixture of each agroecological zone

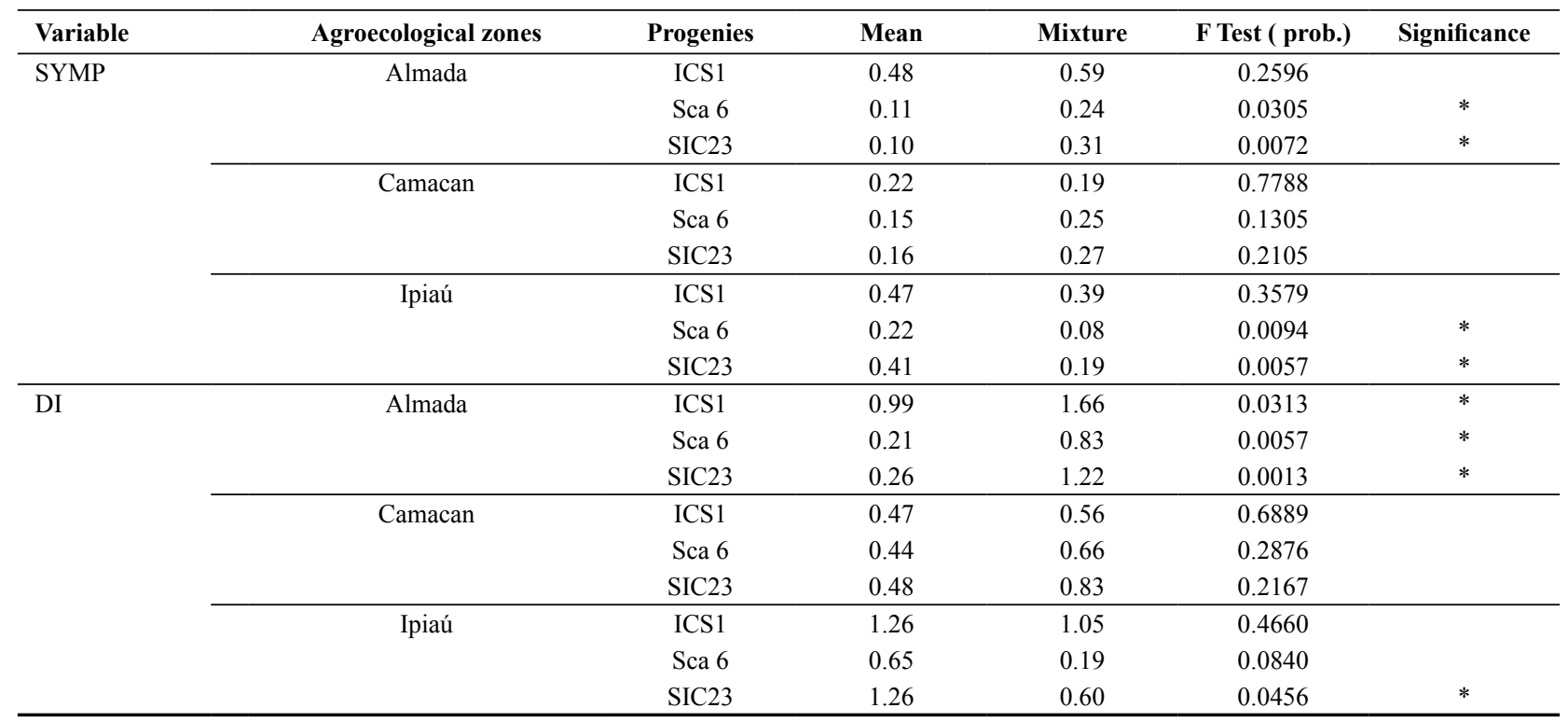

SYMP $=$ presence or absence of witches' broom symptoms; DI = index of witches' broom disease in Theobroma cacao L. progenies; * $=$ significant at $p<0.05$. 
pathogen populations was found earlier among different countries, among regions within countries (Ploetz et al. 2005, Gramacho et al. 2007), among and within municipalities of the cacao region of Bahia, among parts of the same plant (fruits, flower cushions, vegetative shoots) and also among years of observation (Gramacho et al. 2007, Patrocínio et al. 2012). All these studies demonstrated genetic variability in the pathogen, without however addressing the difference in pathogenicity at the level of agroecological zones or municipalities in Bahia. Fungal pathotypes were also observed at the host level, e.g., biotype $\mathrm{C}$ is more cacaospecific and has two pathotypes (A and B). Of these, A occurs in Bolivia, Colombia, Ecuador and is considered more virulent while $\mathrm{B}$, with lower virulence, is found in Brazil (inoculum from Northern Brazil), Trinidad and Tobago, and in Venezuela (Wheeler and Mepsted 1988).

A comparison of the performance of ICS 1, Sca 6 and SIC 23 showed that, regardless of the inoculum source (Figure 1) or progeny $\mathrm{x}$ agroecological zone interaction, progeny ICS 1, with intermediate response to WBD (Luz et al. 1999), was the most susceptible of the three. On the other hand, progeny SIC 23, used as susceptibility standard in trials for selection of resistant genotypes (Pires et al. 1999, Luz et al. 2006), was statistically not different from progeny Sca 6, which is the standard for WBD resistance and, in this study, maintained resistance. The maximum values of SYMP and DI, obtained for progeny Sca 6, were 36 and $1.23 \%$, respectively, when inoculated with basidiospore suspension of brooms from the municipality of Ipiaú (Table 3 ), reinforcing the aggressiveness of this inoculum from the agroecological zone Ipiaú (Table 2). This shows the different performance of cacao genotypes in response to WBD, according to the cultivation site. Therefore, the plant material to be recommended for planting must be previously tested with inocula from different agroecological zones. There is evidence of changes in the performance of progeny ICS 1 and SIC 23, which may be due to the evolution of $M$. perniciosa in the cacao region of Bahia. Clone SIC 23 of the "common type" was strongly affected by the disease in the early $90 \mathrm{~s}$, while nowadays it is less susceptible. The reason is assumed to be the selection pressure on the pathogen to adapt to the resistant genotypes that are being planted.

Evolutionary evidence of the pathogen in Bahia was reported by Gramacho et al. (2008). Similarly, changes in the performance of progeny Scavina were also observed in experimental areas of CEPEC (Paim et al. 2006) as well as on several farms in different municipalities of the region.

The results of this study on the performance of progeny Sca 6 tended to confirm the evidence that the resistance to
WBD of cacao probably involves major and minor genes (Faleiro et al. 2006). The identification of QTL (Quantitative Trait Loci) reinforces this argument (Lanaud et al. 1995, Crouzillat et al. 1996, Motilal et al. 2002, Lanaud et al. 2004, Pugh et al. 2004). This is the reason that progenies of Scavina clones crossed with other resistance sources maintain a resistant performance in the field (Pires et al. 2012). To establish a more durable resistance, several clones that carry genes from various resistance sources have to be planted simultaneously to decrease the selection pressure on the pathogen and the development of more virulent strains.

The variable disease index (DI) used in this study proved reliable for early selection for resistance, to evaluate the progeny performance based on field symptoms that reflect witches' broom severity. Among the most important variables in the early evaluation tests of cacao genotypes, SurujdeoMaharaj et al. (2004) emphasized the terminal broom length and number of axillary brooms. Both symptoms are included in the DI. The routine use of this index is recommended in the performance evaluations of cacao progenies for WBD resistance.

The divergence in the performance of mixtures of inocula from the municipalities in the agroecological zones Almada and Ipiaú (Tables 3 and 4) indicates that care must be taken when recommending inoculum mixtures from different geographical areas in the cacao region to test the witches' broom resistance of genotypes. The tests with mixtures on these and other cacao progenies should be expanded before drawing conclusions about their use to accelerate the early selection process for resistance to witches' broom.

In this way, the variability in the pathogen inoculum from different agroecological zones of the cacao region and between those obtained from municipalities within each agroecological zone was demonstrated, as well as the different performance of the progenies Sca 6, ICS 1 and SIC 23. Particularly Sca 6 and SIC 23 when inoculated with basidiospores of the pathogen from different locations in the region. These results are relevant for cacao breeding as well as for research on the genetic diversity of the pathogen. In practice, it appears that the diversity of pathotypes of the fungus in the cacao region of Bahia may be responsible for the instability of resistance at some locations. This means that in cacao breeding programs for resistance to WBD, the genotypes should be challenged with different pathogen types, mainly if the objective is to develop genotypes and lines with stable resistance, thus avoiding overriding the resistance.

\section{ACKNOWLEDGEMENTS}


This research was supported by the Fundação de Amparo à Pesquisa da Bahia (FAPESB, Brazil). The work of FSS was supported by the FAPESB. The authors are indebted to the Molecular plant pathology laboratory personnel

\section{REFERENCES}

Aime MC and Phillips-Mora W (2005) The causal agents of witches' broom and frosty pod rot of cacao (chocolate, Theobroma cacao) form a new lineage of Marasmiaceae. Mycologia 97: 1012-1022.

Crouzillat D, Lerceteau E, Petiard V, Morera J, Rodríguez H, Walker D, Phillips W, Ronning C, Schnell R, Osei J and Fritz P (1996) Theobroma cacao L.: a genetic linkage map and quantitative trait loci analysis. Theoretical and Applied Genetics 93: 205-214.

Dickstein ER, Purdy LH and Frias GA (1987) Crinipellis perniciosa, the cacao witches' broom fungus: Inoculum production and storage. Phytopathology 77: 1747.

Faleiro GF, Queiroz VT, Lopes UV, Guimarães CT, Pires JL, Yamada MM, Araujo IS, Pereira MG, Schnell R, de Souza GA, Ferreira CF, Barros EG and Moreira MA (2006) Mapping QTLs for witches' broom (Crinipellis perniciosa) resistance in cacao (Theobroma cacao L.). Euphytica 149: 227-235.

Gramacho KP, Pires JL, Lopes UV and Bezerra JL (2008) Vassourade-bruxa, evolução do fungo e necessidade de remoção das partes afetadas em clones resistentes. CEPLAC/CEPEC, Ilhéus, 12p. (Boletim Técnico, 191).

Gramacho KP, Risterucci AM, Lanaud C, Lima LS and Lopes UV (2007) Characterization of microsatellites in the fungal plant pathogen Crinipellis perniciosa. Molecular Ecology Notes 7: 153-155.

Lanaud C, Risterucci AM, N'Goran JAK, Clément D, Flament MH, Laurent $\mathrm{V}$ and Falque M (1995) A genetic linkage map of Theobroma cacao L. Theoretical and Applied Genetics 9: 987-993.

Lanaud C, Risterucci AM, Pieretti I, N'Goran JAK and Fargeas D (2004) Characterization and genetic mapping of resistance and defense gene analogs in cocoa (Theobroma cacao L.). Molecular Breeding 13: 211-227.

Lisboa GJ (1998) Impacto da vassoura de bruxa sobre a produção de cacau no município de Itajuípe-BA. UESC, Ilhéus, 51p.

Lopes UV, Monteiro WR, Pires JL, Clement D, Yamada MM and Gramacho KP (2011) Cacao breeding in Bahia, Brazil: strategies and results. Crop Breeding Applied Biotechnology 11: 73-81.

Luz EDMN, Silva SDVM, Albuquerque PSB, Gramacho KP, Brugnerotto MIB, Paim MCA, Pinto LRM, Lopes UV and Pires JL (1999) Evaluation of cocoa in Brasil, for resistance to Crinipellis perniciosa. In Proceedings of the $12^{\text {th }}$ International Cocoa Research Conference. Copal, Salvador, p. 219-226.
(FITOMOL - CEPEC/CEPLAC) for their assistance with this study, and to Louise Araujo for the technical support in collecting and storing basidiospores. K. P. Gramacho was supported by research fellowships of CNPq.

Luz EDMN, Souza JT, Oliveira ML, Bezerra JL and Albuquerque PSB (2006) VBC: novos enfoques sobre uma velha doença. Revisão Anual de Patologia de Plantas 14: 59-111.

Motilal LA, Sounigo O, Thévenin JM, Risterucci AM, Pieretti I, Noyer JL and Lanaud C (2002) Theobroma cacao L.: Genome map and QTLs for Phytophthora palmivora resistance. In Proceedings of the $1^{\text {th }}$ International Cocoa Research Conference. Copal, Kota Kinabalu, p. 111-118.

Oliveira ML, Gramacho KP and Silva VR (2006) Compatibilidade somática entre isolados de Crinipelllis perniciosa originários da região cacaueira da Bahia. Agrotrópica 17: 53-62.

Paim VRLDM, Luz EDMN, Pires JL, Silva SDVM, Souza JT, Albuquerque PSB and Santos Filho LP (2006) Sources of resistance to Crinipellis perniciosa in progenies of cacao accessions collected in the Brazilian amazon. Scientia Agricola 63: 572-578.

Patrocinio NGRB, Moreira TFC, Serra WO, Pires JL and Gramacho KP (2012) Temporal genetic characterization of isolates of Moniliophthora perniciosa in southeast of Bahia, Brazil. Agrotrópica 24: 169-178.

Pereira JL (1996) Renewed advance of witches' broom disease of cocoa: 100 years later. In Proceedings of the $\mathbf{1 2}^{\text {th }}$ International Cocoa Research Conference. Copal, Salvador, p. 87-89.

Pires JL, Monteiro WR, Pinto LRM and Luz EDMN (1999) Resistance to witches' broom evaluation of genotypes from different origins. In Proceedings of the $12^{\text {th }}$ International Cocoa Research Conference. Copal, Salvador, p. 389-397.

Pires JL, Melo GP, Yamada MM and Gramacho KP (2012) Association among sources of resistance to witches' broom disease for the increment of the level and durability of the character. Agrotrópica 24: $27-30$.

Ploetz RC, Schnell RJ, Ying Z, Zheng OCT, Motamayor JC and Johnson ES (2005) Analysis of molecular in Crinipellis perniciosa with AFLP markers. European Journal of Plant Pathology 111: 317-326.

Pugh T, Fouet O, Risterucci AM, Brottier P, Abouladze M, Delettrez C, Courtois B, Clément D, Larmande P, N'Goran JKA and Lanaud C (2004) A new cacao linkage map based on codominant markers: development and integration of 201 new microsatellite markers. Theoretical and Applied Genetics 108: 1151-1161.

Surujdeo-Maharaj S, Umaharan P and Butler DR (2004) Assessment of resistance to witches'-broom disease in clonal and segregating populations of Theobroma cacao. Plant Disease 88: 787-803. 